\title{
Appropriate Volume Functions for Leguminosae Family in Two Tropical Rainforests in Cross River State, Nigeria
}

\author{
Aigbe Humphrey Igbinosa (Corresponding author) \\ Department of Forestry and Wildlife Management, Faculty of Agriculture, \\ University of Port Harcourt, Choba, Port Harcourt, Nigeria \\ Tel: 234-803-401-0803 E-mail: igaigbe@ yahoo.com \\ Oyebade Bukola Amoo \\ Department of Forestry and Wild life Management, Faculty of Agriculture, \\ University of Port Harcourt, Choba, Port Harcourt, Nigeria \\ Tel: 234-703-446-4789Ｅ-mail: bukola.oyebade@uniport.edu.ng
}

Received: November 18, 2013 Accepted: June 3, $2014 \quad$ Published: December 7, 2014

doi:10.5296/jee.v5i2.6742 URL: http://dx.doi.org/10.5296/jee.v5i2.6742

\begin{abstract}
Volume equations were developed for tree species of leguminosae family in two tropical rainforest, Nigeria. The data used consist of merchantable volume, stump diameter, diameter at breast height and merchantable height for 22 tree species. The number of observations per species ranged from 1 to 30 while the diameter at breast height ranged from $10.00 \mathrm{~cm}$ to $132.20 \mathrm{~cm}$. The result in this study shows that generalised logarithmic volume function (also termed Schumacher's volume function) performed better than other forms of volume functions. For example, the best adjudged volume for all species combined were $\ln V=-0.48205+0.9939 \ln \left(D b h^{2} H\right)$ and $\ln V=-0.78963+1.0391 D s t^{2} H$. The merchantable volume developed from double-variable function indicates negative intercept while the single-variable volume function represents the logarithmic nonlinear function and performed best within the limit of data used for each species group. The method of species grouping in this study was morphological and was based on sub-families of tree species. The
\end{abstract}




\section{Macrothink}

results indicate that $\mathrm{D}^{2} \mathrm{H}$ as weighting factor was found to be appropriate in reducing heteroscedasticity. The model being significant indicates a good fits and confirmed the effectiveness of weighted predictor in stabilising error variance. The resulting volume functions possessed desirable statistical properties and model behaviours, and can be used to estimate timber volume in the tropical rain forest areas of Nigeria. The volume equations based on stump diameter alone are adequate to provide estimates of tree volume illegally removed.

Keywords: Volume equation, Species grouping, Modelling, Mixed tropical forest 


\section{Introduction}

The heterogeneity and high species diversity makes it difficult to understand and predict complex nature of mixed tropical forest. According to Gourlet-Fleury et al., (2005), this difficulty hinders the development of predictive dynamic models, essential for forest managers to simulate logging scenarios for sustainable exploitation. Modeling methodology not only has moved from an empirical approach to a more ecological process-based mechanistic approach, but also has incorporated a variety of techniques due to the dynamic biological systems of mixed tropical forest that are continuously changing (Peng, 1999). There is always a setback in developing separate set of equations for each species due to the existing conditions in the tropical forests and the nature of their dataset. In particular, many species lack sufficient data for reliable estimation of model parameters. On the other hand, pooling together the entire data set of all species for the purpose of fitting volume functions will result in a very large error variance (Akindele and LeMay, 2006). Consequently, the common approach used for modeling forest data is to aggregate species into several groups, and develop separate equations for each group. According to Akindele, (2005), this approach has been used by several authors including Swaine and Whitmore (1988), Vanclay (1991), Chai and LeMay (1993), Atta-Boateng and Moser (1998), Favrichon (1998), Finegan et al. (1999), Gourlet-Fleury and Houllier (2000), Huth and Ditzer (2001) Phillips et al. (2002), Pic ard and Franc (2003), and Zhao et al. (2004). Grouping the species helps to a void the need for specific equations for species with few data, and also facilitates a reduction in the number of functions to a more manageable number (Vanclay, 1991).

Various techniques have been proposed for grouping trees in mixed-species stands. According to Gitay and Noble (1997), there is no universally applicable concept for aggregating species into groups. The type of classification depends on the context of the performed aggregation (Kohler, et al., 2000) and the type of data available (Akindele, 2005). For example, Porte and Bartelink (2002) analysed various criteria that have been used to classify the models. Gourlet-Fleury et al., (2005) suggested three strategies for grouping species for the purpose of modelling in tropical rainforest, they are:

1) Ecological subjective groups;

2) Ecological data-driven groups and

3) Dynamic process groups (corresponding to the components of forest dynamics: recruitment, growth, mortality).

Due to complexity of tropical rainforest, hence there is a need to examine other methods of grouping species. In this study, classification will be based on characteristics community dynamics in terms of sub-families. That means, modelling the tree volume will be based on some properties of the tree characters used for grouping species and this is due to lack of dynamic data to correctly assign each species to a group. The driven force for grouping species in this study is closeness in intra-specific variability of the characters of the tree species. In this case, similarity in physiological and morphological characteristic will be taken into cognisance in grouping the species. This method of species grouping ensures that 


\section{Macrothink}

species are classified according to ecomorphological attributes of the sub-family.

The objectives of this study were to aggregate leguminosae species in two tropical rainforests into sub-family groups and develop appropriate tree volume equations for each group of species. It is hoped that the equations will serve as efficient tools for obtaining reliable estimates of growing stock in the tropical rain forest ecosystem.

\section{Methodology}

\subsection{Study Area}

This study was conducted in the Afi River and Oban Forest Reserves which are located in Cross River State (Fig. 1). The forests are considered as biodiversity hotspot of global significance (Myers et al. 2000, Oates et al. 2004).

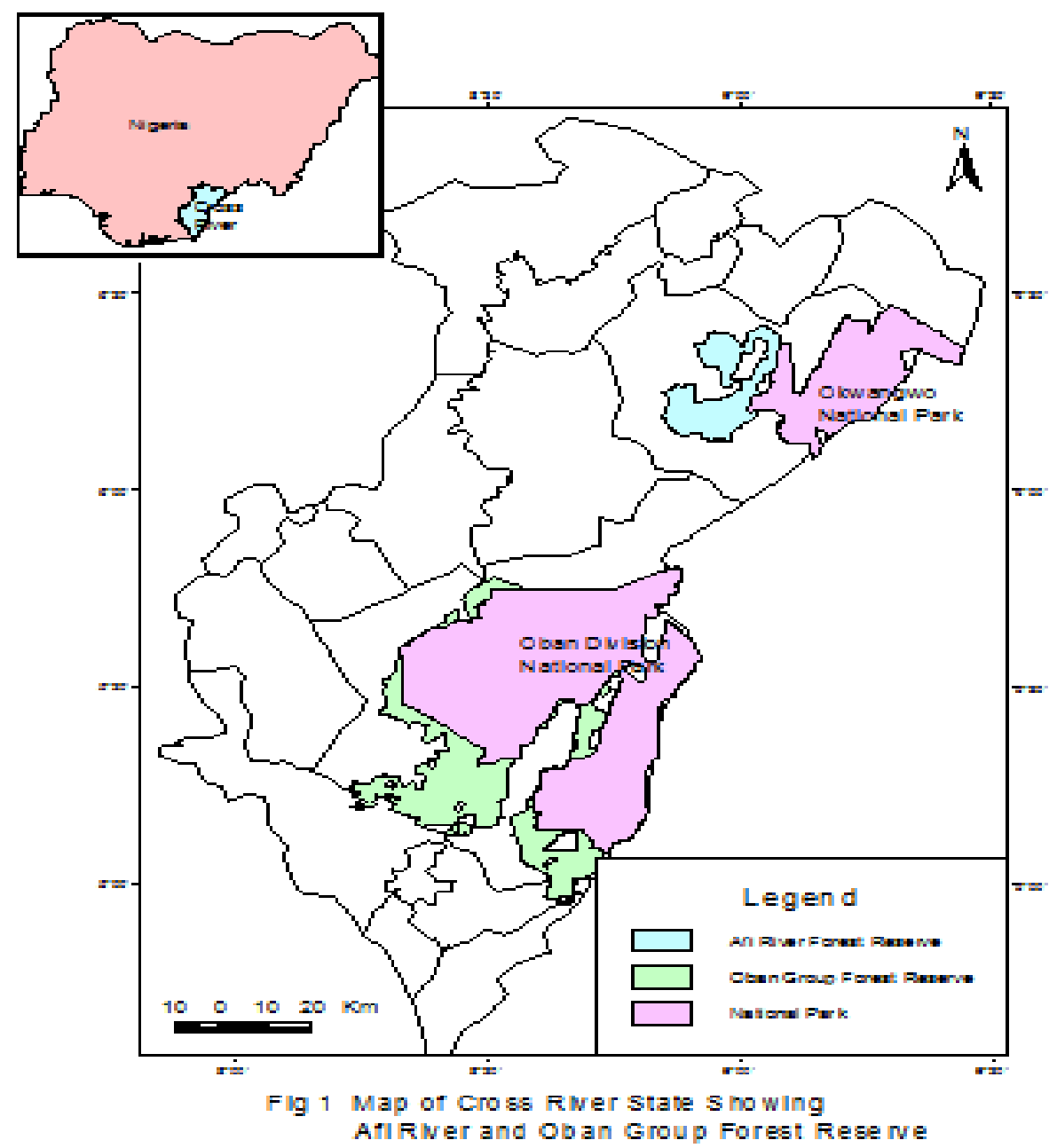

\subsubsection{Afi River Forest Reserve}

Afi River Forest Reserve lies approximately between latitudes $6^{\circ} 08^{\prime}$ and $6^{\circ} 26^{\prime} \mathrm{N}$ and longitudes $8^{\circ} 50^{\prime}$ and $9^{\circ} 05^{\prime} \mathrm{E}$ and covers a total land area of $383.32 \mathrm{~km}^{2}$ including the area known as Afi Mountain. The topography is extremely complex with many connected ridge systems, isolated peaks and outcrops, and ranging between $200 \mathrm{~m}-1200 \mathrm{~m}$ above sea level. 
The reserve is characterized by large tracts of rock outcrops especially on the North-East axis. The hills of the reserve are extension of the Cameroon Mountains geological formation. The fast moving and high gradient streams drain the Afi River Forest Reserve, constituting an important watershed. The geological and soil components can be described as crustaceous sedimentary sandstone occupying a significant area of the study site. In a few places, there are volcanic eruptions through the sedimentary surface and this sometimes comprises columnar basalt (Nsor, 2004).

The Information on the soils of the area is not well documented. Old sedimentary soils tend to be sandy with structure less profiles and incipient laterite. Generally the soils vary from clayey-loam to loamy-clay and normally red with high content of iron oxide. The soils are generally acidic and of low nutrient status, thus not suitable for arable crop production (Agbor, 2003). The entire area falls within a broad annual rain fall zone of 3,000 mm - 3,800 $\mathrm{mm}$ but, with a variation increasing from lowland to uphill (Agbor, 2003). The mean temperatures on Afi Mountain was $22.2^{\circ} \mathrm{C}$, and in the lowland $27.4^{0} \mathrm{C}$. Daily minimum temperatures on Afi Mountain averaged $18.7^{\circ} \mathrm{C}$ and in the lowland $22.1^{\circ} \mathrm{C}$ while an average of $25.8^{\circ} \mathrm{c}$ and $32.8^{\circ} \mathrm{c}$ were recorded as daily maximum temperatures for Afi Mountain and its lowland respectively. Though data on relative humidity, evapo-transpiration and water budgets were never recorded in and around the reserve, but the work of Balogun, (2003) indicate that the mean annual relative humidity is $78 \%$ at $7.00 \mathrm{Hr}$.

The vegetation of Afi River Forest Reserve generally falls within the tropical high forest vegetation zone. The rainforest occupies the foot of the mountain and at about $700 \mathrm{~m}$ part of the forest structure changes gradually into sub-montane vegetation, while above $500 \mathrm{~m}$, parts of the vegetation have been changed into grassland as a result of annual bush fire (Agbor, 2003).

\subsubsection{Oban Forest Reserve}

Oban group forest reserve also known as Oban block forest reserve lies within longitude $8^{\circ} 20^{\prime} \mathrm{E}$ and $8^{\circ} 55^{\prime} \mathrm{E}$ and latitudes $5^{\circ} 00^{\prime} \mathrm{N}$ and $6^{\circ} 00^{\prime} \mathrm{N}$. Presently, it cover an area of $742.55 \mathrm{~km}^{2}$. Topographically, the terrain is rugged and its elevation rises from the river valleys to over $1,000 \mathrm{~m}$ in mountainous areas (Jimoh et al., 2012). Most of the area is characterized by hilly terrain ranging from 100 to over $1,000 \mathrm{~m}$. Greater elevation is accompanied by increased dissection and structural control of drainage. Within the more mountainous areas a rectangular drainage pattern is always noticed. Oban Forest Reserve consists of dominant rock types that are ancient metamorphic rocks of the Basement Complex which cover $50 \%$ of Nigeria. Derived from sedimentary rocks and Precambrian in age these rocks are interspersed with smaller areas of intrusive igneous rocks. The metamorphic rocks are mainly gneisses (biotite-hornblende, granite and migmatitic gneiss and to a lesser extent amphibolite (schist). (Holland et al, 1989; Schmitt, 1996).

Less sandy soils are found in areas with igneous rocks and deeper soils prevail in the plains of the southern part of the park whilst on steeper slopes they are increasingly stony, shallow and erodible (Holland et al, 1989). The annual rainfall is generally, between 2,500mm$3,000 \mathrm{~mm}$. At times, it can be up to $4,000 \mathrm{~mm}$. Temperatures are generally high (average 
around $27^{\circ} \mathrm{C}$ ) and vary little throughout the year with the annual range of the monthly average temperature varying only between $3^{\circ}$ and $3.5^{\circ} \mathrm{C}$. Mean monthly relative humidity varies between $78 \%$ and $91 \%$ with an average of $85 \%$. (Holland et al, 1989; Schmitt, 1996).

\subsection{Data Collection}

Multistage sampling method was adopted in this study. This sampling procedure was made up of primary, secondary and tertiary sampling units. $1000 \mathrm{~m}$ by $1000 \mathrm{~m}$, were randomly chosen, which constitute the primary units. The primary units were divided into secondary 20 units of rectangular plots (otherwise known as strip plot) of $50 \mathrm{~m}$ by $1000 \mathrm{~m}$ ( 5 ha in size), out of which about 4 plots were randomly chosen. The strip plot is a form of rectangular plot often used in tropical rainforest inventory (Colwell, 2009). Each selected secondary units (strip plot) were then divided into 25 equal tertiary plots of $40 \mathrm{~m}$ by $50 \mathrm{~m}(0.20 \mathrm{ha})$ in size, out of which 4 plots were randomly selected. Consequently, the total numbers of sampling plots (tertiary units) for this study were 24 sampling plots. Tree identification and detailed growing stock assessment were undertaken within the tertiary sampling units. The following measurements were made on sampled trees within each of the selected temporary sample plot (i.e. tertiary unit):

i. Outside bark stump diameter (Dst) $(\mathrm{cm})$ at $15 \mathrm{~cm}$ above ground (since a survey of past exploitation showed that no tree is cut below this point) (Akindele, 2003),

ii. Merchantable height (MHT)/m (which is the point between ground level and point of the first surviving whorl of branch),

iii. Outside bark diameter measurements, at base, middle and top positions (taken at a point close to the first surviving whorl of branch).

iv. Outside bark diameter at breast height (Dbh) (taken at $1.3 \mathrm{~m}$ from ground) of trees whose diameter is greater than or equal to $10 \mathrm{~cm}$.

\subsection{Data Analysis}

\subsubsection{Preliminary Data Analysis}

The initial analysis of the data involves the computation of individual tree basal area and volume from the raw data as well as their extrapolation to per-hectare estimates. The individual tree volumes were estimated for the merchantable portion and total stem; the procedures include the following steps.

(1) Computation of basal area of all individual trees using equation 1:

$$
B A=\pi D^{2} / 4
$$

$$
\begin{aligned}
& \text { Where } \mathrm{BA}=\text { basal area }\left(\mathrm{m}^{2}\right) \\
& \begin{array}{l}
\pi=3.142(\text { a constant }) \\
\mathrm{D}=\mathrm{Dbh}(\mathrm{m})
\end{array}
\end{aligned}
$$


Basal area per plot was obtained by adding the basal area of all individual trees within the plot. Mean plot basal area were computed by summing the total plot basal areas of the sample plots selected from the primary unit and dividing by the number of sample plots selected from that primary unit. Basal area per hectare was then obtained by multiplying the mean plot basal area by the number of sample plots per hectare.

(2) The volume of individual trees in each plot were computed using Newton's formula (Husch et al., 2003)

$$
V=h / 6\left(A_{b}+4 A_{m}+A_{t}\right)-
$$

Where:

$$
\begin{aligned}
& \mathrm{V}=\text { tree volume }\left(\mathrm{m}^{3}\right) \\
& \mathrm{h}=\text { tree height }(\mathrm{m}) \\
& A_{b}=\text { Cross -sectional area at the base }\left(\mathrm{m}^{2}\right) \\
& A_{t}=\text { Cross }- \text { sectional area at the top }\left(\mathrm{m}^{2}\right) \\
& A_{m}=\text { Cross }- \text { sectional area at the middle }\left(\mathrm{m}^{2}\right)
\end{aligned}
$$

Volume per plot was obtained by adding the volume of all individual trees within the plot. Mean plot volume were then computed by summing the total volumes of the sample plots selected from the primary unit and dividing by the number of sample plots selected from that primary unit. Volume per hectare was obtained by multiplying the mean plot volume by the number of sample plots per hectare. Following the computation of tree volume and other related variable, the data were summarized by computing simple statistics for each species. The statistics included number of observations per hectare, range, mean and standard error of the mean. Graphs for the species grouped data were also plotted to examine the relationship between the variables.

\subsubsection{Volume Equations for All Species Combined}

In order to have a benchmark with which to compare equations in other categories, several equations were fitted to the combined data set after aggregating all the species into one group. The best equation was chosen to developed volume equation for all species combined.

\subsubsection{Volume Equations for Groups of Species}

All species within same sub-family formed the basis for species grouping. In overall, all the species were grouped into 3 groups based on the number of leguminosae sub-families identified in the two forest reserve. Tree species within each sub-family group were pooled together and tree volume functions were then fitted for each group of species. Series of volume functions were fitted and compared. The equation that produced unbiased estimates as well as residual plots that shows conformity with the assumption of independence of errors 
was considered. Volume equations were developed separately from diameter at breast height (dbh) and stump diameter multivariable for each group. These were considered important from practical point of view.

The volume equation based on stump diameter alone is particularly useful in instances where there is the problem of illegal logging activities, leaving only the stump (Akindele, 1987, 2003). This equation will make it possible to obtain estimates of merchantable volume lost to such illegal activities.

After several trials and comparison of different model forms, the models fitted were weighted quadratic models. They performed best in terms of the fit statistics and randomness of the residuals over the entire range of volume prediction. Some of the several model tried were:

$$
\begin{aligned}
& V=\beta_{1} D^{2} H+\varepsilon_{i} \\
& V=\alpha_{0}+\beta_{1} D^{2} H+\varepsilon_{i} \\
& \operatorname{In} V=\alpha_{0}+\beta_{0}+\beta_{1} \operatorname{In} D \operatorname{In} H+\varepsilon_{i} \\
& V=\alpha_{0}+\beta_{1} D^{2}+\beta_{2} H+\beta_{3} D^{2} H+\varepsilon_{i}
\end{aligned}
$$

Where $\mathrm{V}=$ merchantable volume $\left(\mathrm{m}^{3}\right) ; \mathrm{D}=\mathrm{dbh} / \mathrm{stump}$ diameter $(\mathrm{cm}) ; \mathrm{H}=$ merchantable height (m); $\varepsilon_{\mathrm{i}}=$ error estimate and $\alpha_{0}, \beta_{1}, \beta_{2}$ and $\beta_{3}=$ regression coefficients.

\subsubsection{Criteria for Model Assessment}

The following criteria were used in assessing the fitted equations:

(a) Significance of regression equation using the F-ratio test statistics. The F-ratio is an indication of whether or not the regression equation may be used for prediction. It is given by:

$F=\frac{\text { Re gression Mean Square }}{\text { Error Mean Square }}$

The critical value of $F$ (i.e. $F_{\text {tabulated }}$ ) at $\alpha=0.05$ level is $F\left(v_{1}, v_{2}\right)$, where $V_{1}$ and $V_{2}$ are degrees of freedom for regression and error, respectively. Where the variance ratio (F-calculated) is greater than the F-tabulated, the Null hypothesis is not accepted, and it is concluded that regression is significant. This implies that the regression equation may be used for prediction. The contrary holds where the F-calculated is less than the F-tabulated.

(b) The coefficient of determination $\left(\mathrm{R}^{2}\right)$ : It measures the proportion of variation in the dependent variable that has been accounted for by the linear relationship to the independent variables. $\mathrm{R}^{2}$ is expressed as: 
$R^{2}=\frac{\text { Re gression Sum of Square }}{\text { Total Sum of Square }}$

The coefficient of determination lies between zero and one (i.e. $0 \leq \mathrm{R}^{2} \leq 1$ ). If the decimal fraction is large (i.e. close to 1 ), most of the variability is accounted for by the relationship, and the regression equation is therefore a good prediction equation. If $\mathrm{R}^{2}$ is close to zero the linear model is a poor fit to the data and the regression equation is therefore not very useful.

(c) Standard error of estimate (SEE) and the prediction sum of squares statistic (PRESS) were used to assess the volume equations. The equation(s) with the highest $\mathrm{R}^{2}$ and lowest SEE were chosen and adjudged the best.

$$
\text { Where } \mathrm{R}^{2}=1-\mathrm{ESS} / \mathrm{TSS} \text { - }
$$

$$
\begin{aligned}
& \text { ESS }=\text { Error Sum of Square } \\
& \text { TSS }=\text { Total Sum of Square } \\
& \text { SEE }=\sqrt{ } \text { ESS } / \text { n-p - }
\end{aligned}
$$

$$
\begin{aligned}
& \mathrm{n}=\text { number of observations } \\
& \mathrm{p}=\text { number of estimated coefficient }
\end{aligned}
$$

The final models chosen were analysed with scatter diagram of the residuals over the range of the independent variable to investigate if assumption of independence of residuals is valid and shows conformity with the assumption of independence of errors in regression analysis. That is to investigate if error is normally distributed. The relationships between the variables were also analysed graphically and correlated to show degree of linearity.

\section{Result and Discussion}

\subsection{Preliminary Data Analysis}

Out of total of 1,419 trees that were measured, 364 trees were identified as belonging to leguminosae family. 199 of the trees were identified in Afi River Forest Reserve and 165 trees identified in Oban Forest Reserve. Three sub-families (caesalpinioideae, mimosoideae and papilionoideae) of leguminosae were encountered in the study areas. 10 tree species were identified as belonging to caesalpinioideae, while 7 and 5 tree species belong to mimosoideae and papilionoideae respectively (Table 1). Table 2 shows the result of preliminary data analysis of the trees variables and per hectare estimate. The results indicate that Afi River Forest Reserve and Oban Forest Reserve have an average number of trees per hectare to be 104 and 64 respectively. The numbers of trees per hectare obtained in this study is high in the two forest reserves when compare to the values reported by Adekunle et al, (2004) and Jimoh et al. (2011) for all families in mixed forest. The minimum dbh and stump diameter were $0.111 \mathrm{~m}$ and $0.127 \mathrm{~m}$ for Afi River Forest Reserve and $0.100 \mathrm{~m}$ and $0.120 \mathrm{~m}$ for Oban Forest Reserve respectively. The maximum dbh and stump diameter were $1.800 \mathrm{~m}$ and $1.800 \mathrm{~m}$ for 
Afi River Forest Reserve and $1.20 \mathrm{~m}$ and $1.32 \mathrm{~m}$ for Oban Forest Reserve respectively. The mean dbh and stump diameter obtained are $0.643 \mathrm{~m}$ and $0.704 \mathrm{~m}$ respectively for Afi River Forest Reserve and $0.377 \mathrm{~m}$ and $0.381 \mathrm{~m}$ respectively for Oban Forest Reserve. The two forest types investigated in this study were characterized by abundance of trees with small dbh, especially in Oban Forest Reserve. This trend is not unusual for the tropical rainforests. Similar results have been reported by previous authors in other tropical rainforests of Nigeria (Adekunle et al., 2004; Adekunle and Olagoke, 2008). The reason for relatively fewer number of tree individuals of larger dbh values greater than $0.50 \mathrm{~m}(\mathrm{dbh}>0.50 \mathrm{~m})$ can be attributed to limited number of species that naturally grow up to this diameters class (Hartshorn, 1980) and the numbers of certain big tree species could have been already reduced by selective extraction for some uses in the past (Hadi et al., 2009).

The minimum and maximum merchantable height obtained for Afi River Forest Reserve are $2.70 \mathrm{~m}$ and $55 \mathrm{~m}$ respectively while for Oban Forest Reserve are $2.00 \mathrm{~m}$ and $40 \mathrm{~m}$ respectively. The basal area/ha in this study was lesser in Oban Forest Reserve $\left(8.19 \mathrm{~m}^{2}\right)$ than the Afi River Forest Reserve $\left(42.47 \mathrm{~m}^{2}\right)$. The values obtained in the two forest types were reasonably compared to that suggested by Alder and Abayomi, (1994), for a well-stocked tropical rainforest in Nigeria. This is to be expected since the study area is under protection by law, with minimal human use pressure. The clear difference between basal area per hectare values of Afi River Forest Reserve and Oban Forest Reserve can be attributed to logging and farming activities which more prevalent in Oban Forest Reserve.

The merchantable volumes per hectare recorded for the Afi River Forest Reserve and Oban Forest Reserve are $1,088.80 \mathrm{~m}^{3}$ and $164.54 \mathrm{~m}^{3}$ respectively. The volume per hectare values recorded in this studies is an indication that the reserves are probably one of the richest of the tropical rainforest left in Nigeria when compare to the values reported by previous related researches carried out in other tropical rainforests of Nigeria (e.g. Adekunle et al., 2004; Adekunle and Olagoke, 2008). This may also be indication that, the reserves are probably well protected. The value recorded for Afi River Forest Reserve is higher than that recorded for Oban Forest Reserve. This implies that the Afi River Forest Reserve is better stocked than the Oban Forest Reserve.

Table 1. Results of grouping the 22 tree species by sub-families

\begin{tabular}{lll}
\hline $\begin{array}{l}\text { Group 1 } \\
\text { Caesalpinioideae }\end{array}$ & $\begin{array}{l}\text { Group 2 } \\
\text { Mimosoideae }\end{array}$ & $\begin{array}{l}\text { Group 3 } \\
\text { Papilosoideae }\end{array}$ \\
\hline Afzelia Africana & Albizia ferruginea & Amphimas pterocarpoides \\
Berlinia grandiflora & Albizia gumifera & Baphia nitida \\
Brachystegia eurycoma & Albizia zygia & Pentaclethra macrophylla \\
Daniellia ogea & Cylicodiscus gabunensis & Pterocarpus osun \\
Detarium macrocarpum & Parkia bicolour & Pterocarpus soyauxii \\
Distemonanthus benthamianus & $\begin{array}{l}\text { Piptadeniastrum } \\
\text { africanum }\end{array}$ &
\end{tabular}


Erythrophleum suaveolens

Tetrapleura tetraptera

Gossweilerodendron

balsamiferum

Hylodendron gabunense

Oxystigma mani

Table 2. Summary statistics of the major growth characteristics in the study areas.

\begin{tabular}{|c|c|c|c|c|c|c|c|c|}
\hline \multirow{3}{*}{$\begin{array}{l}\text { Number of } \\
\text { trees/hectare }\end{array}$} & \multicolumn{4}{|c|}{ Afi River Forest Reserve } & \multicolumn{4}{|c|}{ Oban Forest Reserve } \\
\hline & \multicolumn{4}{|c|}{104} & \multicolumn{4}{|c|}{64} \\
\hline & Min & Max & Mean & $\begin{array}{c}\text { Std } \\
\text { Error }\end{array}$ & Min & Max & Mean & $\begin{array}{c}\text { Std } \\
\text { Error }\end{array}$ \\
\hline $\operatorname{Dbh}(\mathrm{m})$ & 0.111 & 1.800 & 0.643 & 0.0257 & 0.100 & 1.200 & 0.363 & 0.0167 \\
\hline $\mathrm{D}_{\mathrm{st}}(\mathrm{m})$ & 0.127 & 1.800 & 0.704 & 0.0265 & 0.120 & 1.322 & 0.406 & 0.0179 \\
\hline $\mathrm{MTH}(\mathrm{m})$ & 2.700 & 55.000 & 26.330 & 0.6690 & 2.000 & 40.000 & 17.86 & 0.5953 \\
\hline $\begin{array}{c}\text { Basal } \\
\text { Area/ha(m²/ha })\end{array}$ & 24.84 & 60.44 & 42.47 & 0.033 & 0.485 & 24.97 & 8.19 & 0.0146 \\
\hline $\begin{array}{l}\text { Merchantable } \\
\text { Vol/ha }\left(\mathrm{m}^{3} / \mathrm{ha}\right)\end{array}$ & 586.50 & 1535.90 & 1089 & 1.058 & 7.68 & 609.67 & 164.54 & 0.3807 \\
\hline
\end{tabular}

Dbh-diameter at breast height, $\mathrm{D}_{\underline{\underline{\underline{s t}}}}$-Outside bark stump diameter, vol-volume

\subsection{Relationship among Variables}

The correlation matrix of the growth attribute for the two forest reserves is presented in Tables 3 and 4. The correlation coefficient shows strongest relationship between $\mathrm{dbh}$ and stump, which proved that stump diameter can be a substitute for $\mathrm{dbh}$ in tree volume estimation. Similar results have been reported for Pines and Oaks (Bylin, 1982), Teak (Osho, 1983), Bald Cypress (Parresol, 1998) and Gmelina arborea (Akindele, 2003) while lowest relationship is between basal area and merchantable height, which to an extent proved that merchantable height is not really a direct factor for size of basal area of tree.

Table 3. Correlation matrix of growth attribute of Afi River Forest Reserve

\begin{tabular}{lcccccc}
\hline & $\mathrm{dbh} / \mathrm{m}$ & $\mathrm{Db} / \mathrm{m}$ & $\mathrm{THT} / \mathrm{m}$ & $\mathrm{MHT} / \mathrm{m}$ & $\mathrm{BA} / \mathrm{m}^{2}$ & $\mathrm{MVol} / \mathrm{m}^{3}$ \\
\hline $\mathrm{dbh} / \mathrm{m}$ & 1 & & & & & \\
$\mathrm{D}_{\mathrm{s} t} / \mathrm{m}$ & 0.992611 & 1 & & & & \\
$\mathrm{THT} / \mathrm{m}$ & 0.85229 & 0.858945 & 1 & & & \\
$\mathrm{MHT} / \mathrm{m}$ & 0.764036 & 0.766196 & 0.876695 & 1 & & \\
$\mathrm{BA} / \mathrm{m}^{2}$ & 0.970369 & 0.95876 & 0.805122 & 0.715887 & 1 & \\
$\mathrm{MVol} / \mathrm{m}^{3}$ & 0.876599 & 0.871098 & 0.757936 & 0.762453 & 0.912689 & 1 \\
\hline
\end{tabular}




\section{Macrothink}

Table 4. Correlation matrix of growth attribute of Oban Forest Reserve

\begin{tabular}{lcccccc}
\hline & $\mathrm{dbh} / \mathrm{m}$ & $\mathrm{Db} / \mathrm{m}$ & $\mathrm{THT} / \mathrm{m}$ & $\mathrm{MHT} / \mathrm{m}$ & $\mathrm{BA} / \mathrm{m} 2$ & $\mathrm{MVol} / \mathrm{m} 3$ \\
\hline $\mathrm{dbh} / \mathrm{m}$ & 1 & & & & & \\
$\mathrm{D}$ st $/ \mathrm{m}$ & 0.991817 & 1 & & & & \\
$\mathrm{THT} / \mathrm{m}$ & 0.811514 & 0.800097 & 1 & & & \\
$\mathrm{MHT} / \mathrm{m}$ & 0.750243 & 0.736653 & 0.948065 & 1 & & \\
$\mathrm{BA} / \mathrm{m} 2$ & 0.951905 & 0.951525 & 0.711379 & 0.62835 & 1 & \\
$\mathrm{MVol} / \mathrm{m} 3$ & 0.91158 & 0.916879 & 0.751416 & 0.69265 & 0.9592 & 1 \\
\hline
\end{tabular}

\subsection{Volume Equations for All Species Combined}

The volume equations for all species combined using dbh and stump diameter multiple variables are presented in equation 11 and 12 respectively. The two equations that were adjudged the best out of the several equations fitted were the logarithmic Schumacher equations of the following forms:

For model form: $\quad \ln V=\alpha_{0}+\beta_{1} \ln \left(D b h^{2} H\right)+\varepsilon_{i}$

$$
\ln V=-0.48205+0.9939 \ln \left(D b h^{2} H\right)
$$

$R=0.990, R^{2}=0.980, R_{\text {ad } j}^{2}=0.980, F$ ratio $=17,673.88, S E E=0.2398$

For model form: $\ln V=\alpha_{0}+\beta_{1} \ln \left(D s t^{2} H\right)+\varepsilon_{i}$

$\ln V=-0.78963+1.0391 D s t^{2} H$

$\mathrm{R}=0.990, \mathrm{R}^{2}=0.980, \mathrm{R}_{\text {ad } \mathrm{j}}=0.980, \mathrm{~F}$ ratio $=17,938.57, \mathrm{SEE}=0.2381$

\subsection{Volume Equations for the Species Groups}

The method of species grouping in this study was morphological and based on sub-families of tree species. Several empirical equations were fitted using dbh and stump diameter multiple-variable volume equations. The best equations that were adjud ged the best (which is the logarithmic schumacher equation) are presented in Tables 5 and 6 . The two tables indicate that the intercept of the equation for all the groups pass through the negative $y$-axis. As noted by Avery and Burkhart (1994), for merchantable volume prediction, negative intercepts are expected. In this study, $\mathrm{D}^{2} \mathrm{H}$ as weighting factor was found to be appropriate in reducing heteroscedasticity. Similar remarks have been made by several authors including Cunia (1964), Snowdon (1985), Philip (1994) and Akindele (2005). The model being significant indicates a good fits and confirmed the effectiveness of weighted predictor in stabilising error 
variance. The results of the single-variable volume equations, using stump diameter only as predictor variable is presented in Table 7. From a series of model-fitting trials, the logarithmic non-linear function performed best within the limit of data used for each species group.

Table 5. Regression statistics for the volume equation for each species group

Model Form: $\ln V=\alpha_{0}+\beta_{1} \ln \left(D b h^{2} H\right)+\varepsilon_{i}$

\begin{tabular}{rccccccc}
\hline Group & $\mathrm{a}_{0}$ & $\mathrm{~b}_{1}$ & $\mathrm{R}$ & $\mathrm{R}^{2}$ & $\mathrm{R}_{\text {adj }}^{2}$ & $\mathrm{SEE}$ & F ratio \\
\hline 1 & -0.471 & 0.985 & 0.987 & 0.975 & 0.975 & 0.277 & 7183.93 \\
2 & -0.502 & 1.006 & 0.994 & 0.988 & 0.988 & 0.165 & 9427.70 \\
3 & -0.475 & 0.998 & 0.992 & 0.983 & 0.983 & 0.241 & 3319.05 \\
\hline
\end{tabular}

Table 6. Regression statistics for the volume equation for each species group

Model Form: $\ln V=\alpha_{0}+\beta_{1} \ln \left(D s t^{2} H\right)+\varepsilon_{i}$

\begin{tabular}{rccccccc}
\hline Group & $\mathrm{a}_{0}$ & $\mathrm{~b}_{1}$ & $\mathrm{R}$ & $\mathrm{R}^{2}$ & $\mathrm{R}_{\text {adj }}^{2}$ & $\mathrm{SEE}$ & F ratio \\
\hline 1 & -0.793 & 1.033 & 0.988 & 0.976 & 0.976 & 0.269 & 7593.15 \\
2 & -0.819 & 1.056 & 0.992 & 0.985 & 0.985 & 0.185 & 7509.13 \\
3 & -0.738 & 1.034 & 0.993 & 0.985 & 0.985 & 0.228 & 3723.06 \\
\hline
\end{tabular}

Table 7. Regression statistics for the volume equation for each species group

Model Form: $\ln V=\alpha_{0}+\beta_{1} \ln D_{s t}+\varepsilon_{i}$

\begin{tabular}{rccccccc}
\hline Group & $\mathrm{a}_{0}$ & $\mathrm{~b}_{1}$ & $\mathrm{R}$ & $\mathrm{R}^{2}$ & $\mathrm{R}^{2}$ adj & $\mathrm{SEE}$ & F ratio \\
\hline 1 & 2.79 & 2.701 & 0.972 & 0.945 & 0.945 & 0.500 & 3171.83 \\
2 & 2.87 & 2.751 & 0.976 & 0.952 & 0.951 & 0.329 & 2289.30 \\
3 & 3.00 & 3.050 & 0.973 & 0.945 & 0.945 & 0.435 & 978.28 \\
\hline
\end{tabular}

\section{Conclusion}

The limiting factor in developing volume equation for mixed tropical rainforest is dearth of data which impairs the development of reliable species-specific volume equations. This problem can be surmounted by aggregating the species into groups and then developing appropriate equations for each species group. Species grouping was done by dividing the species into sub families and developed volume equations for each sub-families of leguminosae.

The generalised logarithmic volume function (also termed Schumacher's volume function) performed better than other forms of volume functions. The equations developed in this study should be very useful in all cases of pre and post-harvest assessment of trees of leguminosae family and can be useful for stock assessment and planning. Developing volume equations from stump diameter is useful in the event that if there is illegal felling of tree, the stump left 
on ground can determine what is removed and offenders appropriately charged. It advisable to use tree volume equations for species groups due to relatively large number of observations instead of the species-specific equations for which sample size was small. The estimation of merchantable tree volumes is essential for understanding of allowable cut cycle and for establishing sustainable forest management in forest reserves. Further and more comprehensive study in this area is recommended. More studies are needed to achieve more applied results.

\section{Reference}

Adekunle V. A. J., \& Olagoke, A. O. (2008). Diversity and biovolume of tree species in natural forest ecosystem in the bitumen-producing area of Ondo State, Nigeria: A baseline $\begin{array}{llll}\text { study. Biodiversity } \quad \text { and } & \text { 2735-2755. }\end{array}$ http://dx.doi.org/10.1007/s10531-007-9279-y

Adekunle, V. A. J., Akindele, S. O., \& Fuwape, J. A. (2004). Structure and yield models of tropical lowland rainforest ecosystem of southwest Nigeria, Food, Agriculture and Environment, 2(2), 395-399.

Akindele, S. O. (2003). Volume Prediction from Stump Diameters of Gmelina arborea trees in Akure Forest Reserve. Nig. J. For., 33(2), 116-123.

Akindele, S. O. (2005). Volume Functions for Common Timber Species of Nigeria's Tropical Rain Forests. A Technical Document submitted to International Tropical Timber Organi-zation (ITTO).

Akindele, S. O., \& LeMay, V. M. (2006). Development of Tree Volume Equations for Common Timber Species in the Tropical rain Forest Area of Nigeria. For. Ecol Manage., 226, 41-48. http://dx.doi.org/10.1016/j.foreco.2006.01.022

Alder, D., \& Abayomi, J. O. (1994). Assessment of data requirements for sustained yield calculations, Unpublished report prepared for the Nigeria Tropical Action Programme, FORMECU, Federal Department of Forestry, Ibadan, Nigeria, p. 28.

Atta-Boateng, J., \& Moser, Jr. J. W. (1998). A method for classifying commercial tree species of an uneven-aged mixed species tropical forest for growth and yield model constru- ction. $\begin{array}{lllll}\text { Forest Ecology } \quad \text { and } & \text { 89-99. }\end{array}$ http://d x.doi.org/10.1016/S0378-1127(97)00243-0

Avery, T. E., \& Burkhart, H. E. (1994). Forest Management (5th ed.). McGraw-Hill Higher Education, New York, US A, p. 408.

Balogun, O. Y. (2003). Senior Secondary School Atlas (2nd ed.), p: 19. Longman. Publishers, Lagos.

Bylin, C. V. (1982). Volume prediction from stump diameter and stump height of selected species in Louisiana. USDA Forest Service, Southern Forest Experiment Station, New Orleans Louisiana. Research paper-182. August 1982. 11p. 
Chai, F. Y. C., \& LeMay V. M. (1993). Development and testing of diameter increment models for mixed swamp forests of Sarawak. Forest Ecology and Management, 58, 51-64. http://dx.doi.org/10.1016/0378-1127(93)90131-6

Cunia, T. (1964). Weighted least squares method and construction of volume tables. Forest Science, 10, 180-19.

Favrichon, V. (1998). Modeling the dynamics and species composition of tropical mixed species uneven-aged natural forest: effects of alternative cutting regimes. Forest Science, 44, 113-124.

Finegan, B., Camacho, M., \& Zamora, N. (1999). Diameter increment patterns among 106 tree species in a logged and silviculturally treated Costa Rican rain-forest. Forest Ecology and Management, 121, 159-176. http://dx.doi.org/10.1016/S0378-1127(98)00551-9

Gitay, H., \& Noble, I. R. (1997). What are functional types and how should we seek them? Pages 3-19. In T. M. Smith, H. H. Shugart, \& F. I. Woodward (Eds.), Plant functional types. Cambridge University Press, Cambridge, UK.

Gourlet-Fleury, S., \& Houllier, F. (2000). Modelling diameter increment in a lowland evergreen rain-forest in French Guiana. Forest Ecology and Management, 131, 269- 289. http://dx.doi.org/10.1016/S0378-1127(99)00212-1

Gourlet-Fleury, S., Blanc L., Picard N., Sist P., Dick J., Nasi R., Swaine M. D., \& Forni., E (2005). Grouping species for predicting mixed tropical forest dynamics: Looking for a strategy. Ann. Forest Science, 62, 785-796. http://dx.doi.org/10.1051/forest:2005084

Hadi. S., Ziegler T., Waltert M., \& Hodges J. K. (2009). Tree diversity and forest structure in northern Siberut, Mentawai islands, Indonesia, Tropical Ecology, 50(2), 315-327.

Hartshorn, G. S. (1980). Neotropical forest dynamics, Biotropica, 12, 23-30. http://dx.doi.org/10.2307/2388152

Holland, M. D., Allen, R. K. G, Barton, D., \& Murphy, S. T. (1989). Cross River National Park (Oban Division); Land Evaluation and Agricultural Recommendations. World Wide Fund for Nature, Godalming, United Kingdom. 140 pp.

Husch, B., Beers, T. W., \& Kershaw Jr. J. A. (2003). Forest Mensuration (4th Ed.). John Wiley and Sons, Inc., New Jersey, USA. 443pp.

Huth, A., \& Ditzer, T. (2001). Long-term impacts of logging in a tropical rain-forest - a simulation study. Forest Ecology and Management, 142, 33-51. http://dx.doi.org/10.1016/S0378-1127(00)00338-8

Jimoh S. O., Adesoye P. O., Adeyemi A. A., \& Ikyaagba E. T. (2012). Forest Structure Analysis in the Oban Division of Cross River National Park, Nigeria. Journal of Agricultural Science and Technology B, 2, 510-518.

Kohler, P., Ditzer, T., \& Huth, A. (2000). Concepts for the aggregation of tropical tree species into functional types and the application to Sabah's lowland rain forests. Journal of Tropical 
Ecology, 16, 591-602. http://dx.doi.org/10.1017/S0266467400001590

Myers, N., Mittermeter, R. A., Mittermeter., C. G., daFonseca, G A. B., \& Kent J. (2000). Biodiversity Hotspot for Conservation Priorities. Nature, 403, 853-858. http://dx.doi.org/10.1038/35002501

Oates, J. F. et al. (2004). Africa's Gulf of Guinea Forests: Biodiversity Patterns and Conservation Priorities. Washington D.C. (Conservation International Center for Applied Biodiversity Science).

Osho, J. S. A. (1983). Volume Prediction from Stump Diameter for Teak (tectona grandis L.f) in Onigambari Forest reserve. Nig J. For., 13(1-2), 53-56.

Parresol, B. R. (1998). Prediction and error of baldcypress stem volume from stump diameter. Southern journal of applied forestry, 22(2), 69-73.

Peng C. (2000). Growth and yield models for uneven-aged stands. Past, present future. Forest Ecology and Mgt., 132, 259-279. http://dx.doi.org/10.1016/S0378-1127(99)00229-7

Philip, M. S. (1994). Measuring tree and forests (2nd ed.). CAB International, Wallingford, UK. 310pp.

Phillips, P. D., Yasman, I., Brash, T. E. \& Gardingen, P. R. (2002). Grouping tree spp. for analysis of forest data in Kalimantan (Indonesian Borneo). Forest Ecology and Mgt. 157, 205-216. http://dx.doi.org/10.1016/S0378-1127(00)00666-6

Picard, N., \& Franc A. (2003). Are ecological groups of species optimal for forest dynamics modeling? $\quad$ Ecological Modelling, $\quad 163, \quad 175-186$. http://dx.doi.org/10.1016/S0304-3800(03)00010-3

Schmitt K. (1996). Zoological survey of the Oban division of Cross River National Park Oban Hill programme, Calabar. Pp 21.

Snowdon, P. (1985). Alternative sampling strategies and regression models for estimating forest biomass. Australian Forest Research, 15(3), 353-366.

Swaine, M. D., \& Whitmore T. C. (1988). On the definition of ecological species groups in tropical rain-forests. Vegetation, 75, 81-86.

Vanclay, J. K. (1991). Tree Volume Equations for Slash Pine. Queensland Forest Service, No. 43.

Zhao, D., Borders, B., \& Wilson, M. (2004). Individual-tree diameter growth and mortality models for bottomland mixed-species hardwood stands in the lower Mississippi alluvial valley. Forest Ecology and Management, 199, 307-322. 